\title{
Frequency and Mechanisms of Factor Independence in IL-3-Dependent Cell Lines
}

\section{Robert J. Isfort}

Genetic Toxicology Section, Human and Environmental Safety Division, The Procter \& Gamble Company, Miami Valley Laboratories, P.O. Box 398707, Cincinnati, Ohio 45239-8707

Volume 16, no. 2, p. 121: Please note that the majority of the research described in this work was performed in the laboratory of Dr. James N. Ihle at St. Jude Children's Research Hospital in Memphis, Tennessee. The funding sources for the research were inadvertantly omitted and an addition to the acknowledgments should read "This research was supported by the American Lebanese Syrian Associated Charities (ALSAC) of St. Jude Children's Research Hospital and by Public Health Service National Cancer Institute Center Support (CORE) Grant P30 CA21765." 